\title{
Viral variability study in follow-up sera from HIV-HBV-HCV coninfected patients
}

\author{
Stefania Taffon ${ }^{1}$, Domenico Genovese ${ }^{1,2}$, Stefano Dettori ${ }^{1}$, Paola Chionne ${ }^{1}$, Claudio Argentini ${ }^{1,2}$, Maria Blasi ${ }^{1}$, \\ Stefania Catone ${ }^{1,2}$, Nicoletta Marino ${ }^{3}$, Francesco Mazzotta ${ }^{3}$, Maria Rapicetta ${ }^{{ }^{*}}$ \\ From $16^{\text {th }}$ International Symposium on HIV and Emerging Infectious Diseases \\ Marseille, France. 24-26 March 2010
}

\section{Background}

The genetic variability of hepatitis $B$ virus in sera from HBV-DNA positive patients, HBsAg negative and antiHBc positive, coinfected with both HIV and HCV, was studied, to describe the natural history of $\mathrm{HBV}$ occult infections.

\section{Methods}

The follow-up sera, encompassing a six to nine years period, from eight patients with triple coinfection (HIV, HBV, HCV) were tested by a real time PCR HBV-DNA assay. Four patients that were HBsAg negative and HBV-DNA positive were classified as affected by occult infection. The remaining four that were $\mathrm{HBsAg}$ positive were used as controls. HBV-DNA was amplified by PCR and the sequence of the whole HBV genome was characterized by phylogenetic analysis (Neighbor Joining method, implemented by MEGA 3.1 software) and for the presence of specific mutations.

\section{Results}

Three out of four HBV patients with occult infection, showed reactivation phases of HBV viremia. Different mutations were observed, with differences between preand post-reactivation sera. HBV-DNA remained at low levels during the entire study period also in absence of specific anti-HBV therapy. The phylogenetic analysis showed that, for each patient with HBV reactivation, all the isolates were originated from a unique parental virus. Specific mutations of PreS/S, Core and X regions were observed.

\footnotetext{
* Correspondence: maria.rapicetta@iss.it

${ }^{1}$ Istituto Superiore di Sanita', Dept. MIPI, Viral Hepatitis Uni, Rome, Italy
}

\section{Discussion}

Mutations in the "a" determinant of the $S$ protein could be responsible for the absence of HBsAg detection. The presence of stop codon in the pre-core region and of mutations in the $\mathrm{X}$ region could, in part, explain the reactivation of $\mathrm{HBV}$ viremia.

\section{Author details}

'Istituto Superiore di Sanita', Dept. MIPI, Viral Hepatitis Uni, Rome, Italy. ${ }^{2}$ Istituto Superiore di Sanita', Dept. FARM, Rome, Italy. ${ }^{3}$ Santa Maria Annunziata Hospital, Infectious Diseases Department, Florence, Italy.

Published: 11 May 2010

doi:10.1186/1742-4690-7-S1-P29

Cite this article as: Taffon et al: Viral variability study in follow-up sera from HIV-HBV-HCV coninfected patients. Retrovirology 2010 7(Suppl 1): P29.
Submit your next manuscript to BioMed Central and take full advantage of:

- Convenient online submission

- Thorough peer review

- No space constraints or color figure charges

- Immediate publication on acceptance

- Inclusion in PubMed, CAS, Scopus and Google Scholar

- Research which is freely available for redistribution

Submit your manuscript at www.biomedcentral.com/submit
C Biomed Central 